\title{
Online Dispute Resolution as Future Dispute Settlement in Indonesia
}

\author{
S Yuniarti \\ Faculty of Humanities, Universitas Bina Nusantara, Jakarta, Indonesia \\ yuniarti@binus.ac.id
}

\begin{abstract}
As part of sustainable development, Alternative Dispute Resolution (ADR) gives citizen more legal access than court system. Using the information technology, Online Dispute Resolution (ODR) raised as a variant of ADR. ODR is believed as a system that resolve dispute effectively, efficiently, and able to resolve cross-border dispute. In the beginning of its development, the ODR was identical to resolving disputes between consumer and business actor. However, in many countries, ODR is applied to other types of dispute. In accordance with achieve sustainable development goals on peace, justice and strong community, Indonesia needs to aknowledge ODR on Indonesia legal system. This paper is normative legal research that found ODR has not covered by a specific regulation. However, ODR has been applied to resolve the dispute in Indonesia. Therefore, to provide a legal certanity, Indonesia needs to set up both ODR regulation and system.
\end{abstract}

Keywords: Alternative Dispute Resolution (ADR), Online Dispute Resolution $(O D R)$, Dispute

\section{INTRODUCTION}

In 2015, United Nations sets 17 global goals of the Sustanaible Development Goals (SDGs) that will be targeted achieve at 2030. Peace, justice and strong institutions is one of such goals that targeted to promote peacefull and inclusive societies for sustainable development, provide access to justice for all and build effective, accountable and inclusive institutions at all levels. UNDP acknowledged that without peace, stability, human rights and effective governance, people cannot hope for sustainable development. Access to justice is trying to provide legal system and rules should be equally accesible to every citizen, include to settle any disputes occured.

Definition of a dispute according to Black's Law Dictionary is a conflict or controversy; claim or rights conflict [1]. The use of information and communication technology supported by internet networks increases the frequency of human interaction. Intensity of the intersection has the potential to produce conflicts and create disputes. The complexity of the dispute arises when disputes involve more than one jurisdiction as a result of the cross boarder activity.In settling disputes, there are 2 (two) dispute resolution, namely litigation and non-litigation or known as ADR. ADR arises from unsatisfactory of the inefficient judicial system. ADR referes to wide range of dispute resolution exclude the dispute mechanism of litigation.ADR increase access to justice for social groups that are not adequately or fairly served by the 
judicial system [2]. Furthermore, with the use of technology in the ADR's process, there were variations of ADR is namely Online Dispute Resolution (ODR) that believe more effective and efficient, and able to resolve cross-border disputes.

\section{LITERATURE REVIEW}

This paper is a normative legal research.The research is using secondary data collected through a literature study with regulations as the primary legal source. To support this paper, it also collecting information regarding ODR in Indonesia practically and other coutries as well.

\section{RESULT AND DISCUSSION}

\subsection{Online Dispute Resolution}

Online Dispute Resolution (ODR) is raise as a variant of ADR that involved technology on the process. Similiar terminology for ODR are Internet Dispute Resolution (iDR), Electronic Dispute Resolution (eDR), Electronic ADR (eADR) and Online ADR (oADR).According to Pablo Cortes, ODR is incorporates all methods used to resolve disputes that are conducted on the internet through a tailored online platform [3]. Collin Rule, co-founderModria, said that ODR is the application of information and communications technology to the practice of dispute resolution [4]. Therefore, utilization of information and communication technology is a must on ODR.

According to Van Arsdale, technologies use in ODR are: (1) communication technologies; and (2) automation technology, algorithms, and artificial intelligence [5]. An ODR platform may use algorithms and party input to automate the decision-making and settlement process. Artificial intelligence technologies are used more for intelligent negotiation and decision support than as a substitute for the advice and guidance of attorneys or the evaluation or judgment of a neutral.Later on, Lodder and Zeleznikow said that ODR systems may be divided according to the forms of synchronous and asynchronous communication used [6]. At the first type, parties may communicate with each other in real time by using Messenger or Skype. In the asynchronous form, communication is not conducted at the same timeand is therefore less direct-for example by using e-mail.

In general the type of ODR is similar to the type of ADR. Dispute resolution through ODR can be divided into four types, namely: (1) Online settlement, using the system automatically to resolve disputes and financial claims; (2) Online Arbitration, use the website to resolve disputes with the help of qualified third parties as arbitrators; and (3) Consumer complaints resolution center, using e-mail to handle various types of complaints and consumer complaints. From type of service provider, ODR can be carried out by the private sector or the government. There are two types of private ODR platforms: self-contained and full service [7]. A selfcontained ODR platform is designed to resolve disputes within a community, such as in an online marketplace. A full service platform is open to any disputefor whom the ODR method is appropriate according to dispute type,cost, or other factors, such as Mondria.

\subsection{Implementation of ODR in Other Countries}

Historically, e-commerce has triggered the need for ODR. This background makes ODR more widely used to resolve disputes between businesses and consumers. Referring to the understanding that ODR is a variant of ADR, ODR is suppose to be used for all possible 
disputes through ADR. In fact, ODR is applied to settle not only consumer dispute. According to implementation of ODR in others countries, ODR is flexible to apply for civil dispute and also possible to to resolve litigation cases classified as small claims. Implementation of ODRin other countries are [8], [9]:

Table 1. Implementation of ODR in Other Countries.

\begin{tabular}{cl} 
Countries & \multicolumn{1}{c}{ Area } \\
England & Consumer complain for services provided by \\
& lawyer or claims to management company. \\
Autralia & Divorce \\
Ohio, USA & Civil dispute including city tax issues, small \\
& claims, credit card debt, landlord-tenant \\
& issues, and other disputes \\
& under $\$ 6,000$ \\
Michigan,USA & Family court compliance, small claims, \\
& parking tickets, and outstanding warrants
\end{tabular}

\subsection{Implementation ODR in Indonesia}

ASEAN places ODR as part of the ASEAN Economic Community Blueprint since 2008. However, Indonesia does not hava a specific rules related to ODR. Considering nature of ODR as a varian of ADR, Act No. 30/1999 regarding Arbitration and Alternative Dispute Settlement is using to legitimate the exixtency of ODR. Later on, related to dispute occured from electronic system, ODR is also possible to be applied under Act No.11/2008 as amended with Act No. 19/2016 regarding Information and Transaction Electronic and Act No. 7/2014 regarding Trade.

Table 2. Legal Basis of ODR in Indonesia.

\begin{tabular}{|c|c|}
\hline $\begin{array}{l}\text { Article } 1 \text { paragraph }(10) \text {, } \\
\text { Article } 6 \text { ADR Act }\end{array}$ & $\begin{array}{l}\text { Type of ADR acknowledge are consultation, negotiation, } \\
\text { mediation, conciliation, or expert judgment. Procedure of } \\
\text { ADR as stated in Article } 6 \text { does not regulate specific methode } \\
\text { how ADR should be implemented. }\end{array}$ \\
\hline $\begin{array}{l}\text { Article } 4 \text { paragraph (3) ADR } \\
\text { Act }\end{array}$ & $\begin{array}{l}\text { In the event the parties agreed to held arbitration through a } \\
\text { letter exchange, e-mail or other communications means } \\
\text { acknowledged correspondence. }\end{array}$ \\
\hline $\begin{array}{l}\text { Article } 65 \text { paragraph }(5) \\
\text { Trade Act }\end{array}$ & $\begin{array}{l}\text { A dispute occured from a commercial transaction through an } \\
\text { electronic system can resolve through the court or other } \\
\text { dispute resolution mechanisms. }\end{array}$ \\
\hline $\begin{array}{l}\text { Article } 18 \text { paragraph }(4) \\
\text { Information and Transaction } \\
\text { Electronic Act }\end{array}$ & $\begin{array}{l}\text { On international electronic transaction, the parties entitle to } \\
\text { establish an alternative court, arbitration, or alternative dispute } \\
\text { settlement forum. Such forum included those conducted } \\
\text { electronically, are forums chosen by the parties. }\end{array}$ \\
\hline
\end{tabular}

Refer to ADR Act, ODR is still possible to be applied since there is no specific methode how ADR should be implemented. It could be interpreted online and offline. On arbitration process, ADR Act is allowed to conduct the process online that provide oppurtunity to create 
an arbitration online. However, according to Information and Transaction Electronic Act,ODR is only implemented for an international electronic transaction that means involved more than a national juridiction. Under the Trade Act, wide range of implementation is more possible. Other dispute resolution mechanisms as stated in the Trade Act shall be interprented as ADR and ODR. Similiar interpretating shall be applied to any stipulations that using terminology "other dispute resolution mechanism" or "alternative dispute resolution".

Although Indonesia does not have rules that specifically regulate ODR, in practice ODR has been implemented.The implementation ODR in Indonesia are:

Table 3. Implementation ODR in Indonesia.

\begin{tabular}{ll}
\hline Type of Dispute & Provider of ODR Service \\
\hline Domain name & PANDI \\
\hline Financial service & Indonesian Alternative Dispute Settlement Institution on \\
& Banking (LAPSPI), Indonesian Capital Market Arbitration \\
& Board(BAPMI), Pension Fund Mediation Agency \\
& (BMDP),Indonesian Insurance Mediation and Arbitration \\
& Board (BMAI), Agency Indonesian Arbitration and \\
& Mediation Security Company (BAMPPI), and Indonesian \\
& Financing, Pawnshop and Venture Mediation \\
& Board(BMPPVI). \\
\hline Consumer dispute & Bukalapak, Tokopedia \\
\hline
\end{tabular}

Registration of domain name is handled by PANDI (Internet Domain Name Register). One of the PANDI authorities is to handle domain name dispute. Domain name dispute is an objection on the use of registred domain name without authority, or violate other's rights, or registering under negative intention and/or against legislation in force.According to PANDI's regulation No.005/K/DNP/Domain Name Dispute Policy/II/2018/PANDI-Public, domain name dispute shall be prioritised by using mediation.Unless the parties remain in their own opinion, then the investigation of dispute matter be fully authorized by PPND Panel under the policy. The implementation of the objection process as well as the submission of evidence and other correspondence is carried out electronically.

Later on, related to financial services provided by Financial Service Institution (LPK) that regulated and monitored by OJK (Financial Fervices Authority). OJK has facilitate complaintsconsumers are through the formation of Consumer ServicesIntegrated Finance (or often referred to as Financial

OJK Customer Care (FCC) to handle question and complain from customer or society. The FCC has provided a varietychannels for consumers and the public to deliverrequest for services to OJK, such as contact centers, letters,e-mail, facsimile and mobile application. Besides, related to dispute between consumen and LPK, through OJK Regulation Number $1 /$ POJK.07 / 2014 concerning Alternative InstitutionsDispute Settlement in the Financial Services Sector, OJK set up an 10 (ten) Alternative Dispute Settlement Institution. Procedure of each Altermative Dispute Settlement is using electronic communication suche-mail, teleconference, video conference.

As part of e-commerce, marketplace growth significally in Indonesia. To improve the service to consumen, some marketplace provides alternative disputes settlement between consumen and business actors electronically such as Bukalapak and Tokopedia. As concluded on the websites, methode of ODR prefer by Bukalapak and Tokopedia are negotiation and 
mediation. Negotiation in Tokopedia conducted between the parties on a system provided by marketplace namely Resolution Center. In the event, the negotiation is failed, Tokopedia will assist the parties as a mediator. While Bukalapak set that consumen shall contact Bukalapak first before the dispute submit to district court. Bukalapak will assist the parties to achieve a settlement.

\section{CONCLUSION}

In Indonesia, ODR has been implemented in some area. However, a specific ODR regulation is not exist. There are at least 3 (three) reasons that ODR needs to be regulated specifically in Indonesia. First, practically the ODR has been implemented in Indonesia. Second, member of ASEAN agree to set up a national ODR system in accordance to harmonization.Third, the ODR provides access to justice for citizen. Existency of ODR shall assist Indonesia to achieve one of sustainable development goals that is peace, justice and strong institutions, especially to fulfill access to justice.

\section{REFERENCES}

[1] B. A. Garner and H. Black, C Black's law dictionary. St. Paul, Minn: West Publishing, 2009.

[2] D. Fairman and Cervenak C, Alternative dispute resolution practitioners guide. USA: USAID, 2000.

[3] P. Cortés, Online dispute resolution for consumers in the European Union. London: Routledge, 2010.

[4] C. Rule, "Techology and future of dispute resolution," Dispute Resolution Magazine, vol. 84 , no. 1, p. $5,2015$.

[5] A. S. Van, "User protections in online dispute resolution," Harvard Negot. Law Rev., vol. 21, no. 4, p. 120, 2001.

[6] A. R. Lodder and J. Zeleznikow, "Norms for the use of technology in dispute resolution," in Enhanced Dispute Resolution Through the Use of Information Technology, Cambridge University Press, pp. 18-38.

[7] A. Raymond and S. Shackelford, "Technology, Ethics and Access to Justice: Should an Algorithm Be Deciding Your Case?," SSRN Electron. J., 2013.

[8] D. Lavi, "No more click?click in here:e-mediation in divorce disputes-the reality and the desirable," 2015, vol. 13, no. 16, p. 479.

[9] T. J. Committee, "Case studies in ODR for courts: A view from the front lines," JTC Resour. Bul., vol. 2, no. 1, p. 2, 2017. 